\title{
Analysis of Brand Experience, Brand Satisfaction and Brand Trust Relationship to Brand Attachment
}

\author{
Deni Wardani \\ Indonesia Banking School \\ deni@ibs.ac.id \\ Reza Rekayasa Gustia \\ Indonesia Banking School \\ reza.rekayasa@gmail.com
}

\begin{abstract}
In this modern age, people are required to have a high social mobility. The increasing number of private cars is resulted from the growing number of middle class in Indonesia. The main focus of this study was to analyze the effect of brand experience, brand satisfaction, brand trust towards brand attachment. this research is classified as descriptive analysis method to take samples and questionnaire as the main tool. The sample was 150 BMW users, especially those who have a BMW car in Jakarta. Respondents were selected using non probability sampling techniques and sampling convince. The results of analysis using structural equation model (SEM) found evidence for following relationships: brand experience significant positive effect on brand satisfaction, but it is not significant on brand trust. It has also found that brand satisfaction has significant positive effect on brand trust and brand attachment. However, brand satisfaction is found not having significant positive effect on brand attachment.
\end{abstract}

Keyword: brand experience, brand satisfaction, brand trust, brand attachment

Di zaman yang modern ini, manusia dituntut untuk memiliki mobilitas sosial yang tinggi. Meningkatnya jumlah kendaraan pribadi ini tidak lepas dari fenomena pertumbuhan jumlah kelas menengah di Indonesia. Fokus utama dari penelitian ini adalah untuk menganalisis pengaruh brand experience, brand satisfaction, dan brand trust terhadap brand attachment. 
Penelitian ini dikategorikan sebagai metode analisis deskriptif dengan mengambil sampel dan kuisioner sebagai alat utama. Sampel penelitian ini adalah pengguna BMW sebanyak 150 orang terutama mereka yang mempunyai mobil BMW di Jakarta. Responden dipilih dengan menggunakan teknik non probability sampling dan convience sampling. Hasil analisis menggunakan Structural Equation Model (SEM) dan hasilnya adalah sebagai berikut: 1. Pengalaman merek berpengaruh positif signifikan terhadap kepuasan merek. 2. Pengalaman merek tidak berpengaruh positif signifikan terhadap kepercayaan merek. 3. Kepuasan merek berpengaruh positif signifikan terhadap kepercayaan merek. 4. Kepuasan merek tidak berpengaruh positif signifikan terhadap keterikatan merek. 5. Kepercayaan merek berpengaruh positif signifikan terhadap keterikatan merek

Kata Kunci: Pengalaman merek, kepuasan merek, kepercayaan merek, keterikatan merek.

\section{Background}

In this modern era, humans are expected to have high social mobility. Social mobility can be defined as change, shift, improvement, or lowering of their role as member. Therefore, social mobility is someone or a group movement from one layer to another layer. With necessity to have high mobility, humans are expected to do mobility quickly in conducting any daily activity. With that necessity, it causes rise of demand and society's need of having adequate transportation facility.

This research took BMW as the object to observe. BMW car can still be classified as CBU (completely built up) product. According to an article in www.cnnindonesia.com, as a car producer, BMW was adding its investment in Indonesia following increasing demand of BMW products in Indonesia. Even though BMW has factory to manufacture its car in this country, spare-part and the other components are still produced overseas.

PT BMW Indonesia is established in 2001 and the production of BMW in Indonesia is handled by PT Astra International Tbk. To increase worldwide trade growth, one of the ways is increasing economic growth in a country. Cited from carmudi.com, even though domestic is flagging, it does not hinder BMW Group Indonesia to launch new models of its yard vehicle. BMW Indonesia also realized that automotive market in Indonesia is declining. However, The German manufacturer believes that the condition will be getting better towards the end of the year. 


\section{Theoretical Basis}

The theoretical basis of this research stemmed from various marketing concepts. Predominantly marketing and branding, especially in brand experience. Marketing management is the process of analyzing, implementing, coordinating, and controlling the program, which involves the conception, pricing, promotion, and distribution of products, services and ideas that are designed to create and maintain favorable exchange with the target market for the purpose of achieving organizational goals. (Walter, Cleff, \& Chu, 2013).

Brand is a very important factor for the success of a company. The Company will make every effort so that their brands widely known. The impact of word of mouth is felt to be the most important thing for a company to make consumers knowing their judgement about a brand. Word of mouth will give direct impact towards brand knowledge (Louis, Lombart, \& Louis, 2010) after the formation of brand knowledge that will eventually give influence on the formation of brand relationship.

Brand experience according to Brakus, Schmitt, \& Zarantonello, (2009) is a subjective response (sensation, feelings, and minds) and consumer behavior that is triggered by a stimulus associated with a brand such as design and identity (name, logo, packaging, and communication (brochure and website) as well as the environment (the outlets)).

Brand satisfaction as a result of consumer's subjective evaluation in which consumers feel satisfied with their chosen brand and the brand matches their expectations. Brand satisfaction can be categorized into two, they are transaction specific satisfaction and accumulative satisfaction (Zboja \& Voorhees, 2006).

Brand trust is an acknowledgement that brand value can be created and developed by managing some aspects that exceed consumer satisfaction upon product functional performance and it attritubes (Aaker, 1996). Brand Attachment is defined as power of attachment that connect brands and self. Based on attachment theory (Park, et al., 2010) the attachment is shown by strong and rich memory network and it can be accessed or presented by mental that involves thought and feeling on brand and brand connection for self. 


\section{Conceptual Framework and Hyphothesis Development}

The overall model of the research tries to give understanding on the relationship between the constructs investigated namely: brand experience, brand satisfaction, brand tryst and brand attachment (Figure 1)

Positive brand experience happens when net value of good interaction with brand exceeding negative value (Chinomona, 2013). This is perceived net value leads to brand satisfaction. Thus, when the perceived value derived from the brand experience is high, so is brand satisfaction (Meyer \& Schwager, 2007). Thus the hyphothesis 1 as follows:

$\mathrm{H} 1$ : Brand experience has positive influence on brand satisfaction

Brand experience is a different empiric from other brand and it is a concept focusing on consumer including brand attachment, brand involvement and consumer delight (Brakus et al., 2009). Brand experience has strong correlation with brand trust because if consumers have tried to use the product and they feel satisfied thus, consumers will trust the brand.

$\mathrm{H} 2$ : Brand experience has positive influence on brand trust

Satisfaction is a direact measurement on customer staying loyal on certain brand. Satisfaction becomes main measurement where needs and desires of customer on certain products can be fulfilled. The previous researched found that there is a positive correlation between brand satisfaction and brand trust (Chinomona, 2013).

H3: Brand satisfaction has positive influence on brand trust

The Influence of Brand Satisfaction on Brand Attachment

Evidence of marketing management literature proves that consumers are more satisfied with the brand, the greater the consumer identification with the brand because of the essence satisfaction of (Bhattacharya and Sen, 2003; Whan Park et al., 2010). According to Chiu, Huang and Yen (2010), very satisfied customers tend to reflect the traits of brand personality using some symbols associated with the brand as an expression of their attachment to the brand.

H4: Brand satisfaction has positive influence on brand attachment

Consumers who believe in brand are ready to increase and maintain affective attachment with the brand that has made them satisfied. Affective attachment will eventually reach the peak 
in brand attachment (Büschken, 2004; Keh, Nguyen \& Ng, 2007). Therefore, the higher the trust level of the brand, the more it is expected to cause strong brand attachment.

H5: Brand trust has positive influence on brand attachment

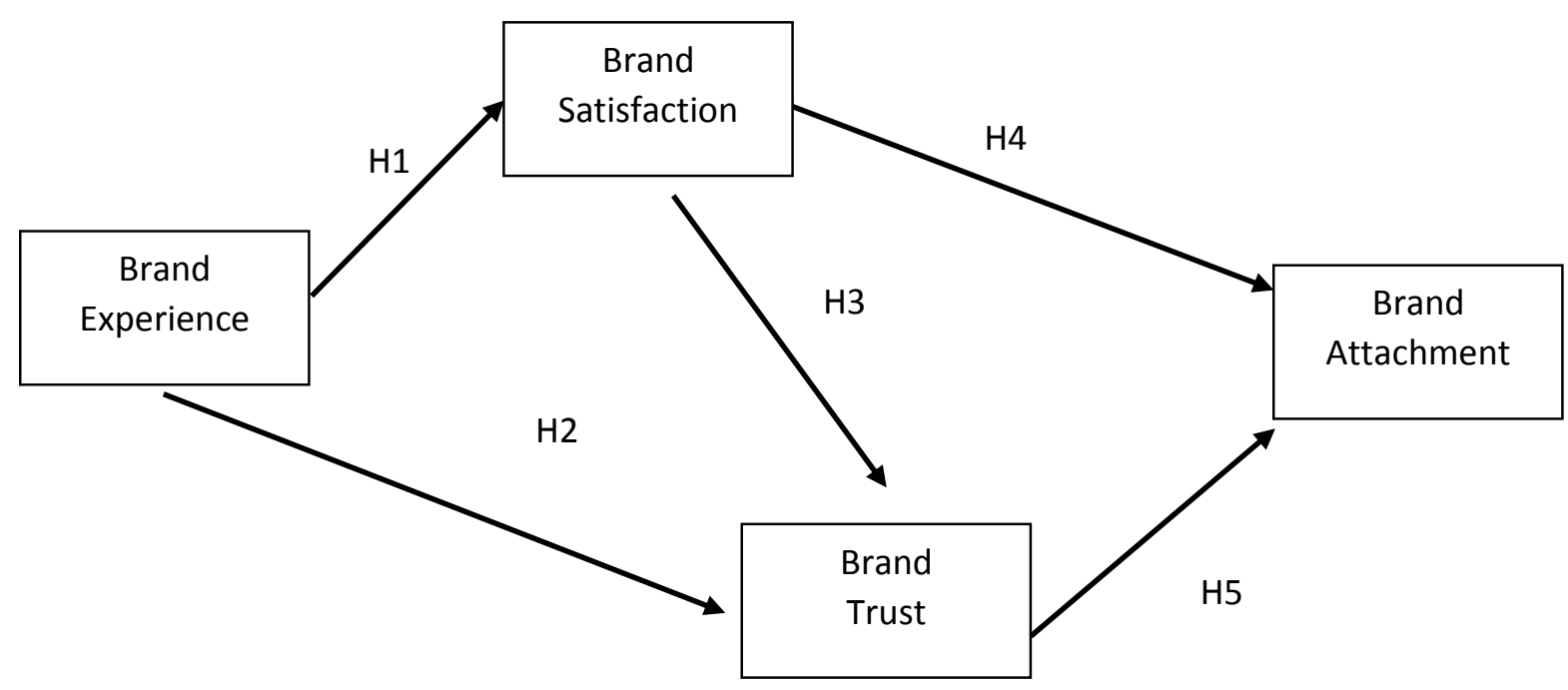

Figure 1. Research Model

Sources: Adopted from Richard Chinomona (2013)

\section{Research Method}

Research Object

Research Object of this academic writing was BMW car user in Jakarta for all type of $\mathrm{BMW}$ car. The researcher used respondents who use BMW car as research analysis unit.

\section{Research Design}

It is a quantitative research design. According to Sugiyono (2008) A descriptive research is a research conducted to know the value of independent variables, both one variable or more than one (independent) without making comparison, or connecting with other variables. Quantitative research method itself has aim to measure data and it is common to take form statistical analysis (Malhotra, 2010). 


\section{Data Collecting Method}

To complete this research this research used primary and secondary data. The primary data is directly obtained by the researcher for specific purpose in answering research problem (Malhotra, 2010). In this research, primary data was collected through survey method that used structured questionnaire distributed to respondent that is BMW user. While secondary data is collected by other parties from various sources such as books, internet, as well as research journal that has significance on research topic. Secondary data can be obtained from books that has correlation with this research such as information from literature books, journal, and related publications.

\section{Population and Sample}

Population is a combination of all elements that has sequence of similar characteristic (Maholtra, 2010). In this research, the sample was BMW car riders of all type and all series of BMW starting from the first establishment of PT BMW Indonesia in 2001. Total number of this sample referred to (Hair, et al., 2010), minimum number of sample is at least five times more than number of measurement that will be analyzed and more acceptable size of sample. In this research, number of measurement were 23 questions. Therefore, researcher multiplied that number with 6,5 to have number of sample as much as $149,5=150$ respondents.

\section{Analysis and Explanation}

\section{Respondent's Profile}

Respondent's Profile was done to explain and describe demography and characteristic of respondent overall based on gender, age, latest education, and occupation. Out of 150 respondents, 112 respondents were male and 38 respondents were female. It shows that male respondents are more than female respondents. It is because the research object is BMW car.

\section{Result of Data Analysis}

Based on data analysis method that was chosen on previous chapter, research used AMOS 22 software as supporting analysis tool of Structural Equation Model. AMOS 22 was chosen because it is easy to use and result of data analysis in the form of graphic model can 
be known directly. End result of AMOS 22 can be seen in additional structural model software used in this research that is Microsoft Office Excel 2007 and SPSS 23.

\section{Managerial Implication}

According to result of this research, Managerial Implication is given to BMW Group Indonesia as facility provider. Some of Implications for BMW are as follow:

First is implication related to Brand Experience. In tighter competition, customers tend to prioritize Brand Experience that is gained with basis of higher expected result of quality than customer's expectation. Brand Experience given by BMW should definitely be maintained as well as improved to achieve more optimum result for customer. BMW physical display becomes important aspect and also a sense that will be felt by every customer such as modern look display, attractive display for customer, and the best performance become the basis of customer rating quality of goods that will be used later. When the experience is perceived at a car that's good then it would be a great confidence in the eyes of the public. Therefore, BMW should provide a good and optimum experience that allow users to get brand satisfaction.

Secondly, is on the area of increasing satisfaction level. Brand Satisfaction refers to practical benefit that can be felt by customers when they use BMW products. Gained satisfaction should match the expected and desired experience and service and higher than expectation of customer. BMW should meet the needs of its customer so that BMW users experience satisfaction on the products and it is supposed to be maintained and improved in order that the service given to customers can work to its maximum service such as giving comfort on periodic service for BMW products (free service and free spare part for 5 years to customers who buy new BMW). Today, there are many BMW special car shop that provide service and spare part of BMW car. Therefore, BMW car user will feel satisfied with BMW products when they will have used it.

Lastly is the implication regarding Brand Trust. Brand Trust is a degree of satisfaction gained in products according to experience and satisfaction that is earned from a BMW product. Trust is created based on greater satisfaction of BMW user on car and services produced by BMW which it matches all expectation wanted by BMW after using products and services of BMW. If BMW has given its promises such as good quality products, 
satisfying service, and free service for 5 years have been fulfilled, customers will have Brand Trust towards BMW.

\section{Conclusion and Recommendation}

\section{Conclusion}

This research was conducted to examine the influence of BMW car Customer's Brand Experience on Brand Satisfaction, Brand Trust, and Brand Attachment. Result of data analysis conducted by using SEM analysis shown that all hypothesis had positive and significant influence. By studying the examination on Brand Experience, Brand Satisfaction, Brand Trust, and Brand Attachment of BMW car customers, it can be inferred that:

1. Brand Experience has positive influence on Brand Satisfaction.

2. Brand Experience does not have significant influence on Brand Trust.

3. Brand Satisfaction has positive influence on Brand Trust.

4. Brand Satisfaction does not have significant influence Brand Attachment.

5. Brand Trust has positive influence on Brand Attachment.

\section{Recommendation}

Result of this research has shown that there is positive and significant influence on each hypothesis. This research obviously still has shortcomings thus; it still needs to perfect for future research. Therefore, several recommendations that can be given to the company and future researcher.

The first recommendation is to create good brand experience and get brand satisfaction for BMW car, BMW needs to open manufacture factory and the spare part in Indonesia that BMW can manufacture the car easily in Indonesia and it can use spare part that has been made in Indonesia that it does not need to send spare part and other things from overseas. Thus, price market for BMW car will become more realistic in Indonesia. Second recommendation is BMW needs to have advertisement in TV and Radio to foster a sense of interest towards BMW hence to create better and positive result in terms of sensory. Another recommendation is to improve experience. BMW products need to follow every exhibition and provide test drive for all type of car so that it will create direct attachment during trial of BMW products and it will foster curiosity towards BMW car. If all aspects in 
Brand Experience such as sensory affective, behavior, and intellectual have been fulfilled, high brand experience will happen. Brand Trust in this context can give good impact if BMW can offer a product with constant level of quality, helping BMW customer to solve problem when they use BMW products. Perceiving the user of BMW product as a valuable individual.

For future research, the object can be replaced with other object outside automotive company. Future research can also add more variables such as brand awareness, brand image (Rudolf \& Schmit, 2006) and brand personality (Brakus et al, 2009) hence, it will enrich the research and there might be more detailed and beneficial for both researcher and examined objects.

\section{References}

Aaker, D. (1996). Measuring Brand Equity. California Management Review.

Bhattacharya, C. B., \& Sen, S. (2003). Consumer-Company Identification: A Framework for Understanding Consumers' Relationships with Companies. Journal of Marketing.

Brakus, J. J., Schmitt, B. H., \& Zarantonello, L. (2009). Brand Experience: What Is It? How Is It Measures? Does It Affect Loyalty? Journal of Marketing, 73(May), 52-68.

Caruana, A. (2002). Service loyalty: The effects of service quality and the mediating role of customer satisfaction. European Journal of Marketing, 36(7/8), 81182

Chaudhuri, A., \& Holbrook, B. (2001). The Chain and to Brand Performance: The Role of Brand Loyalty. Journal of Marketing, 65(2), 81-93.

Chinomona, R., \& Sandada, M. (2013). Customer Satisfaction, Trust and Loyalty as

Predictors of Customer Intention to Re-Purchase South African Retailing Industry. Mediterranean Journal of Social Sciences, 4(14), 437-446.

Chiu, C.-M., Huang, H.-Y., \& Yen, C.-H. (2010). Antecedents of trust in online auctions. Electronic Commerce Research and Applications, 9(2), 148-159.

Cooper, D. R., \& Schindler, P. S. (2010). Business Research Methods. Social Research.

De Ruyter, K., Moorman, L., \& Lemmink, J. (2001). Antecedents of Commitment and Trust in Customer-Supplier Relationships in High Technology Markets. Industrial Marketing Management, 30(3), 271-286.

Eriksson, J. (2011). The Relationship between Customer Satisfaction and Service Quality: a study of three Service sectors in Umeå . 
Ha, H.-Y., \& Perks, H. (2005). Effects of consumer perceptions of brand experience on the web: Brand familiarity, satisfaction and brand trust. Journal of Consumer Behaviour, 4(6), 438-452.

Hair, J. F., Black, W. C., Babin, B. J., Anderson, R. E., \& Tatham, R. L. (2010). Multivariate Data Analysis. Prentice Hall.

Hanzaee, K. H., \& Andervazh, L. (2012). An analysis of some moderating variables on the value, brand trust and brand loyalty chain. Research Journal of Applied Sciences, Engineering and Technology, 4(2), 1403-1413

Jin, H. S., Suh, J., \& Donavan, D. T. (2008). Salient Effects of Publicity in Advertised Brand Recall and Recognition: The List-Strength Paradigm. Journal of Advertising, 37(1), 4557.

Keh, H. T., Nguyen, T. T. M., \& Ng, H. P. (2007). The Effects of Entrepreneurial Orientation and Marketing Information on the Performance of SMEs. Journal of Business Venturing, 22, 592-611

Kuenzel, S., \& Halliday, S. V. (2008). Investigating Antecedents And Consequences Of Brand Identification. Journal of Product \& Brand Management, 17(5), 293-304.

Lau, G. T., \& Lee, S. H. (1999). Consumers' trust in a brand and the link to brand loyalty. Journal of Market-Focused Management, 4(4), 341-370.

Louis, D., Lombart, C., \& Louis, D. (2010). Impact of brand personality on three major relational consequences (trust, attachment, and commitment to the brand).

Malhotra. (2010). Marketing Research: An Applied Orientation (Upper Sadd). Prentice Hall.

Meyer, C., \& Schwager, A. (2007). Understanding customer experience. Harvard Business Review, 85(2), 117-126.

Nam, J., Ekinci, Y., \& Whyatt, G. (2011). Brand equity, brand loyalty and consumer satisfaction. Annals of Tourism Research, 38(3), 1009-1030.

Reardon, J., Miller, C., Vida, I., \& Kim, I. (2005). The effects of ethnocentrism and economic development on the formation of brand and ad attitudes in transitional economies. European Journal of Marketing, 39(7/8), 737-754.

http://doi.org/10.1108/03090560510601743Riel, A. C. R. Van, Liljander, V., \& Jurriëns, P. (2001). Exploring consumer evaluations of e-services: a portal site. International Journal of Service Industry Management, 12(4), 359-377.

Rundle-Thiele, S., \& Bennett, R. (2001). A brand for all seasons? A discussion of brand loyalty approaches and their applicability for different markets. Journal of Product \& Brand Management, 10, 25-37. 
Şahin, A., Zehir, C., \& Kitapçi, H. (2011). The effects of brand experiences, trust and satisfaction on building brand loyalty; an empirical research on global brands. Procedia - Social and Behavioral Sciences, 24, 1288-1301.

Sugiyono, (2008). Metode Penelitian Kunatitatif Kualitatif dan $R \& D$. Bandung Alfabeta.

Walter, N., Cleff, T., \& Chu, G. (2013). Brand experience's influences on customer satisfaction and loyalty: A Mirage in Marketing Research? International Journal of Management Research and Business Strategy, 2(1).

Wang, Y. D. ;, \& Emurian, H. H. (2005). An overview of online trust: Concepts, elements, and implications. Computers in Human Behavior, 21.

Whan Park, C., MacInnis, D. J., Priester, J., Eisingerich, A. B., \& lacobucci, D. (2010). Brand Attachment and Brand Attitude Strength: Conceptual and Empirical Differentiation of Two Critical Brand Equity Drivers. Journal of Marketing, 74(6), 1-17.

Wijanto, S. H. (2008). Structural Equation Modeling dengan Lisrel 8.8 (Konsep dan Tuturial). Yogyakarta: Graha IImu.

Zarantonello, L., \& Schmitt, B. H. (2010). Using the brand experience scale to profile consumers and predict consumer behaviour. Journal of Brand Management, 17(7), 532-540.

Zboja, J. J., \& Voorhees, C. M. (2006). The impact of brand trust and satisfaction on retailer repurchase intentions. Journal of Services Marketing, 20, 381-390

Zhou, Z., Zhang, Q., Su, C., \& Zhou, N. (2012). How do brand communities generate brand relationships? Intermediate mechanisms. Journal of Business Research, 65(7), 890895.

www.gurupendidikan.com/pengertian-manajemen-pemasaran-menurut-para-ahli/

www.data.jakarta.go.id/dataset/data-perbandingan-jumlah-kendaraan-pribadi-danangkutan-umum-dki-jakarta/resource/.

www://ekbis.sindonews.com/read/674375/34/fenomena-kebangkitan-kelasmenengah-1348459350.

www.brandirectory.com.

www.carmudi.com, 2015

http://www.forbes.com/powerful-brands/list/, 2015

http://pusatdata.kontan.co.id/makroekonomi/mobil?bulan=09\&tahun=2015, 2015 
www.cnnindonesia.com, http://www.cnnindonesia.com/ekonomi/20150410155749-92-

45750/genjot-pabrik-perakitan-bmw-tambah-modal-35-juta-euro/, 2015

https://brandsite.wordpress.com/category/keterikatan-merek/, 2015

\section{Attachment}

Operational Variables

Table 1. Operational Variables

\begin{tabular}{|c|c|c|c|c|}
\hline No. & Variable & Definition & Indicator & $\begin{array}{l}\text { Scale of } \\
\text { Measurement }\end{array}$ \\
\hline \multirow{8}{*}{1} & \multirow{8}{*}{$\begin{array}{c}\text { Brand } \\
\text { Experience }\end{array}$} & \multirow{8}{*}{$\begin{array}{l}\text { Brand experience is } \\
\text { defined as sensation, } \\
\text { thoughts, cognitive, } \\
\text { and behavioral } \\
\text { responses in creating } \\
\text { a push of a brand in } \\
\text { terms of design and } \\
\text { brand identity, } \\
\text { packaging, } \\
\text { communication, and } \\
\text { environment. Brand } \\
\text { Experience includes } 4 \\
\text { dimension, they are: } \\
\text { 1. Sensory, } \\
\text { 2. Affective, } \\
\text { 3. Intellectual, } \\
\text { 4. Behavioural } \\
\text { (Brakus et. al, } \\
\text { 2009) }\end{array}$} & $\begin{array}{l}\text { BE 1-BMW Brand create strong } \\
\text { sense on my sense of sight or } \\
\text { other sense. }\end{array}$ & \multirow{8}{*}{ Likert 1-7 } \\
\hline & & & $\begin{array}{l}\text { BE } 2 \text { - I found BMW brand } \\
\text { interesting sensory. }\end{array}$ & \\
\hline & & & $\begin{array}{l}\text { BE } 3 \text { - BMW Brand is } \\
\text { interesting for my sensory. }\end{array}$ & \\
\hline & & & BE $4-$ BMW brand affect me & \\
\hline & & & $\begin{array}{l}\text { BE } 5 \text { - BMW brand is } \\
\text { memorable for me }\end{array}$ & \\
\hline & & & $\begin{array}{l}\text { BE } 6 \text { - I am directly involved } \\
\text { when I am using products of BMW } \\
\text { brand. }\end{array}$ & \\
\hline & & & $\begin{array}{l}\text { BE } 7 \text { - BMW brand gives a } \\
\text { real experience for me }\end{array}$ & \\
\hline & & & $\begin{array}{l}\text { BE } 8 \text { - BMW brand triggers } \\
\text { curiosity on me } \\
\text { (Brakus et. al, } \\
\text { 2009) }\end{array}$ & \\
\hline
\end{tabular}


Table 2. Operational Variables

\begin{tabular}{|c|c|c|c|c|}
\hline No. & Variables & Definition & Indicators & $\begin{array}{l}\text { Scale of } \\
\text { Measurement }\end{array}$ \\
\hline \multirow{6}{*}{2} & \multirow{6}{*}{$\begin{array}{l}\text { Brand } \\
\text { Satisfaction }\end{array}$} & \multirow{6}{*}{$\begin{array}{l}\text { Brand satisfaction is } \\
\text { defined as overall } \\
\text { satisfaction felt by the } \\
\text { consumers according } \\
\text { to evaluation of all } \\
\text { consumers upon } \\
\text { number of buying and } \\
\text { consumer's experience } \\
\text { with a product or a } \\
\text { service of a brand } \\
\text { (Nguyen, } \\
\text { 2011) in } \\
\text { (Chinomona, 2013) }\end{array}$} & $\begin{array}{l}\text { BS } 1-\text { I am very satisfied with } \\
\text { what is provided by the BMW } \\
\text { brand. }\end{array}$ & \multirow{6}{*}{ Likert 1-7 } \\
\hline & & & $\begin{array}{l}\text { BS } 2-\text { I'm very satisfied } \\
\text { with the BMW brand. }\end{array}$ & \\
\hline & & & $\begin{array}{l}\text { BS } 3 \text { - I am very happy } \\
\text { when I am using the BMW brand. }\end{array}$ & \\
\hline & & & $\begin{array}{l}\text { BS } 5 \text { - Service and product } \\
\text { provided by the BMW brand are } \\
\text { very satisfying. }\end{array}$ & \\
\hline & & & $\begin{array}{l}\text { BS } 6 \text { - I always get the satisfying } \\
\text { experience } \\
\text { when I am using BMW brand. }\end{array}$ & \\
\hline & & & $\begin{array}{l}\text { BS } 7 \text { - I make } \\
\text { the right decision when } \\
\text { I decide to } \\
\text { use BMW Brand. } \\
\text { (Chinomona, 2013) }\end{array}$ & \\
\hline \multirow{4}{*}{3} & \multirow{4}{*}{ Brand Trust } & \multirow{4}{*}{$\begin{array}{l}\text { Brand Trust is the } \\
\text { readiness of } \\
\text { consumers to believe } \\
\text { in a brand even } \\
\text { though it is risky } \\
\text { because there is an } \\
\text { expectation that the } \\
\text { brand will give positive } \\
\text { result (Lau and Lee, } \\
\text { 1999) }\end{array}$} & $\begin{array}{l}\text { BT } 1 \text { - I believe in } \\
\text { BMW brand }\end{array}$ & \multirow{4}{*}{ Likert 1-7 } \\
\hline & & & $\begin{array}{l}\text { BT } 2 \text { - I really rely on BMW } \\
\text { brand }\end{array}$ & \\
\hline & & & BT 3 - BMW is an honest brand & \\
\hline & & & $\begin{array}{l}\text { BT } 4 \text { - I feel safe } \\
\text { when I am using BMW brand } \\
\text { (Chinomona, 2013) }\end{array}$ & \\
\hline
\end{tabular}


Table 3. Operational Variables

\begin{tabular}{|c|c|c|c|c|}
\hline No. & Variables & Definition & Indicators & $\begin{array}{l}\text { Scale of } \\
\text { Measurement }\end{array}$ \\
\hline \multirow{4}{*}{4} & \multirow{4}{*}{$\begin{array}{c}\text { Brand } \\
\text { Attachment }\end{array}$} & \multirow{4}{*}{$\begin{array}{l}\text { Brand Attachment } \\
\text { Is defined as power of } \\
\text { attachment that } \\
\text { connect brands ith } \\
\text { individual. This } \\
\text { attachment is shown } \\
\text { by rich and accessible } \\
\text { network of memory or } \\
\text { present mental that } \\
\text { involve thought on } \\
\text { brand and connection } \\
\text { of brand and self. } \\
\text { (Chinomona, 2013) }\end{array}$} & $\begin{array}{l}\text { BA } 1 \text { - I am very } \\
\text { passionate about the brand BMW. }\end{array}$ & \multirow{4}{*}{ Likert 1-7 } \\
\hline & & & $\begin{array}{l}\text { BA } 2 \text { - BMW brand triggers } \\
\text { strong enthusiasm in myself. }\end{array}$ & \\
\hline & & & $\begin{array}{l}\text { BA } 3-\text { I will remain } \\
\text { using BMW brand for longer time }\end{array}$ & \\
\hline & & & $\begin{array}{l}\text { BA } 4-\text { I sacrifice important thing to } \\
\text { get BMW brand. } \\
\text { (Chinomona, 2013) }\end{array}$ & \\
\hline
\end{tabular}

